\title{
Determining the association between fibromyalgia, the gut microbiome and its biomarkers: A systematic review
}

\author{
Sharon Erdrich ${ }^{1 *}$ D, Jason A. Hawrelak², Stephen P. Myers ${ }^{3}$ and Joanna E. Harnett ${ }^{1}$
}

\begin{abstract}
Background: The association between fibromyalgia and irritable bowel syndrome is well-established. Alterations in the composition and diversity of the gut microbiome in irritable bowel syndrome have been reported, however, this association is poorly understood in fibromyalgia.

Our aim was to summarise the research reporting on the gastrointestinal microbiome and its biomarkers in people with fibromyalgia.

Methods: A systematic review of published original research reporting on the gastrointestinal microbiota and its biomarkers in adults with a diagnosis of fibromyalgia was undertaken.

Results: From 4771 studies, 11 met our inclusion criteria and were separated into four main groups: papers reporting Helicobacter pylori; other gut bacterial markers; metabolomics and other biomarkers, which included intestinal permeability and small intestinal bacterial overgrowth.

Conclusion: The results suggest there is a paucity of quality research in this area, with indications that the gut microbiota may play a role in fibromyalgia within the emerging field of the gut-musculoskeletal axis. Further investigations into the relationship between the gut microbiota, gut dysfunction and fibromyalgia are warranted.
\end{abstract}

Keywords: Fibromyalgia, Fibromyalgia syndrome, Gastrointestinal microbiome, Biomarkers, Systematic review

\section{Background}

It has been almost half-century since the term fibromyalgia replaced fibrositis [1], yet the condition remains idiopathic, poorly understood and difficult to treat [2]. Its cardinal symptom is pain, which must be both widespread and chronic to meet the current diagnostic criteria.

The prevalence of fibromyalgia shows large variability. A review of 39 studies conducted across 19 countries indicates prevalence ranges from 0.2 to $6.6 \%$ [3]. The associated morbidity is not insignificant and the costs, both

\footnotetext{
* Correspondence: Sharon.erdrich@sydney.edu.au

${ }^{1}$ Faculty of Medicine and Health, School of Pharmacy, The University of Sydney, Sydney, New South Wales, Australia

Full list of author information is available at the end of the article
}

direct and indirect, contribute to a significant socioeconomic burden [4].

Without laboratory evaluations that contribute to the diagnosis of the condition, it is also difficult to diagnose [5]. Therefore, clinical presentation of the typical pain and the presence of associated somatic and psychological symptoms form the basis of current diagnosis.

To date the pathophysiology of fibromyalgia remains elusive. No causative agent has been identified, however, a role for a range of different infections has been suggested [6]. Nervous system dysfunction is implicated and neurotransmitters are the targets of a number of drugs approved for fibromyalgia [7]. Recently, Albrecht and colleagues have suggested a possible role for microglial activation and neuroinflammation [8]. Pathological

(C) The Author(s). 2020 Open Access This article is licensed under a Creative Commons Attribution 4.0 International License, which permits use, sharing, adaptation, distribution and reproduction in any medium or format, as long as you give appropriate credit to the original author(s) and the source, provide a link to the Creative Commons licence, and indicate if changes were made. The images or other third party material in this article are included in the article's Creative Commons licence, unless indicated otherwise in a credit line to the material. If material is not included in the article's Creative Commons licence and your intended use is not permitted by statutory regulation or exceeds the permitted use, you will need to obtain permission directly from the copyright holder. To view a copy of this licence, visit http://creativecommons.org/licenses/by/4.0/ The Creative Commons Public Domain Dedication waiver (http://creativecommons.org/publicdomain/zero/1.0/) applies to the data made available in this article, unless otherwise stated in a credit line to the data. 
changes in epidermal nerve fibres has also been implicated, with evidence for the association nearing 50\% [9]. The role of oxidative stress, autoimmune markers, proteomics, genetics and a range of hormones have all been implicated with inconsistent results [10]. Inflammation has never been clearly identified. A systematic review and meta-analysis of 13 studies reporting inflammatory biomarkers in fibromyalgia found only plasma interleukin-6 (IL-6) to be higher in patients, compared to controls.

Fibromyalgia is associated with a range of somatic symptoms and gastrointestinal disorders. Our group have recently conducted a systematic review of the comorbidity of FGID in fibromyalgia and found this area to be under-explored, with the majority of studies focusing on irritable bowel syndrome (IBS) [11]. IBS has been associated with alterations in the composition and diversity of the gastrointestinal microbiota [12]. Individuals with both fibromyalgia and IBS report higher symptom severity and poorer quality of life $[13,14]$. Interest in the role of the gastrointestinal microbiome on both the gut- brain axis and systemic disorders has increased exponentially in recent years and a comprehensive review of this topic as it relates to fibromyalgia is warranted.

The aim of this systematic review was to examine and summarise the research reporting on the composition and diversity of the gut microbiome and associated biomarkers in adults with fibromyalgia.

\section{Methods}

This review was registered with PROSPERO (https:// www.crd.york.ac.uk/PROSPERO/). [registration number pending].

\section{Data sources}

A search of Medline, CINAHL, Embase and Web of Science databases was made using the terms in Table 1, conducted over 06-08 August 2019. Results were exported into EndNote X9.2 (Thomson Reuters Inc., Philadelphia, PA, USA.) and duplicate records deleted.

Table 1 Search used for the Medline database to identify literature reporting on fibromyalgia and terms related to gut microbiome and/or biomarkers of gut bacteria

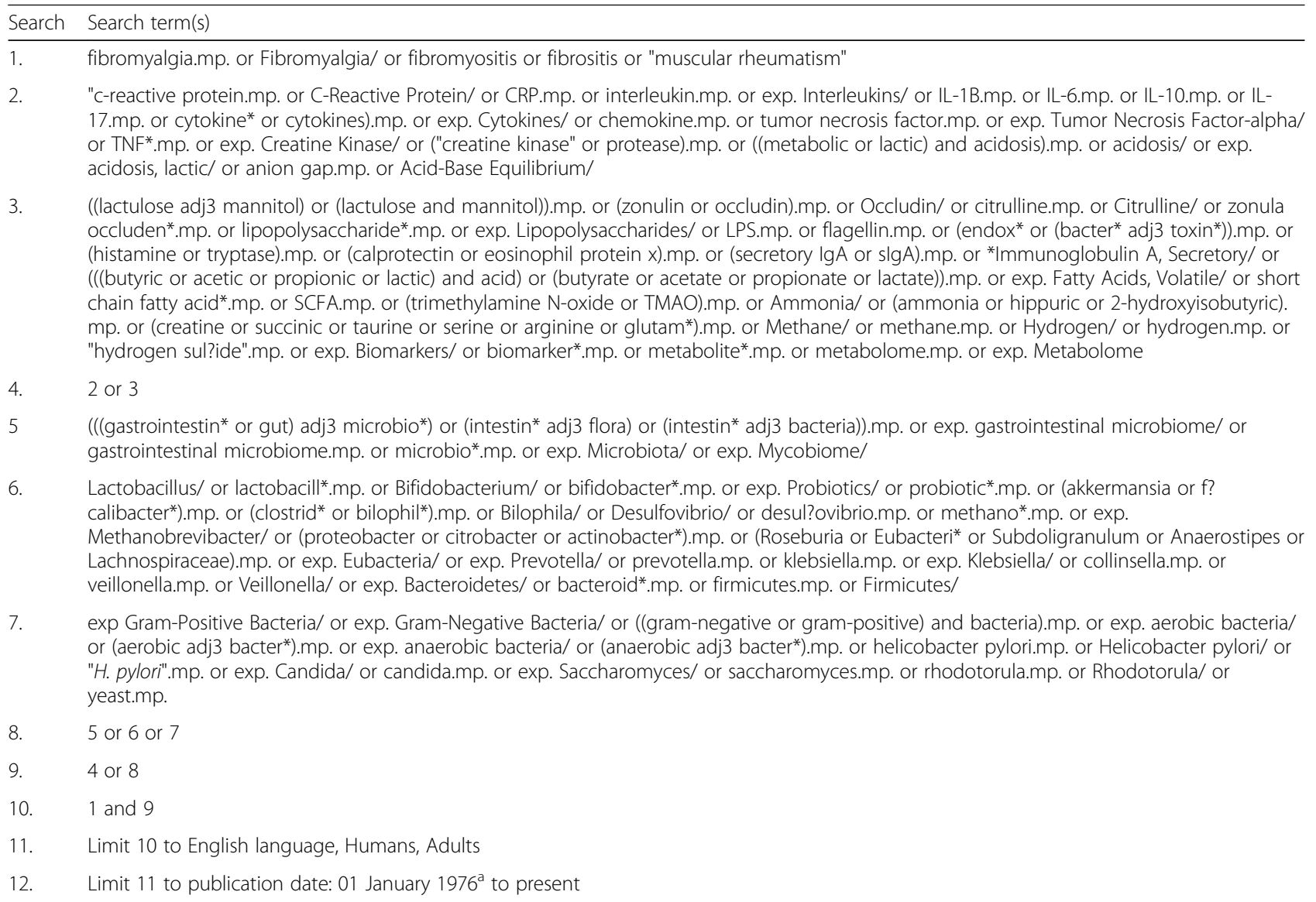

Limit 11 to publication date: 01 January $1976^{a}$ to present

athe year "fibromyalgia" became the official term for the condition 1. Inanici F, Yunus MB: History of fibromyalgia: past to present. Current Pain and Headache Reports 2004, 8(5):369-378 


\section{Study selection}

Further screening to remove conference abstracts, studies involving children ( $<18$ years of age), animals, reviews, case reports or papers irrelevant to our objectives. Full-text articles were retrieved and linked to the corresponding EndNote record. Reference lists of included articles were reviewed for other studies relevant to our objectives. Articles were scanned for diagnostic criteria used; those not specifying accepted guidelines for diagnosis were excluded. We also excluded papers reporting systemic biomarkers not evaluated in the context of gastrointestinal symptoms or gut flora.

The selection process is presented in Fig. 1, utilising the Preferred Reporting Items for Systematic Reviews and Meta-Analyses (PRISMA) flow diagram [15].

\section{Data extraction}

The following data was extracted to a Microsoft $^{\circ}$ Excel $^{\circ}$ spreadsheet: lead author, year, country of publication, gender and age of cohort, diagnostic criteria used for fibromyalgia, bacteria or biomarker thereof reported, summary of results.

\section{Quality assessment}

All studies were reviewed by two authors (SE and JEH) who screened for inclusion criteria and conducted a quality assessment using the Joanna Briggs critical appraisal tool "Checklist for case-control studies" [16], with additional quality criterion including: diagnostic criteria used to identify fibromyalgia, the description of cohort/s, and evidence that ethics/consent had been granted, giving a total of 16 criteria for evaluation. Scores were then converted to percentages for reporting.

\section{Results}

A total of 4771 articles were retrieved. The PRISMA flow diagram (Fig. 1) shows the selection process and number of studies included and excluded at each step to arrive at the final eleven studies, conducted in 7 countries, included in this analysis. There was a high degree of heterogeneity across the studies, which were of variable quality (Table 2).

A total of 618 subjects with fibromyalgia ( $90 \%$ female $[n=554])$, and 635 controls, of whom $180(29 \%)$ had other health conditions were included. Two papers presented

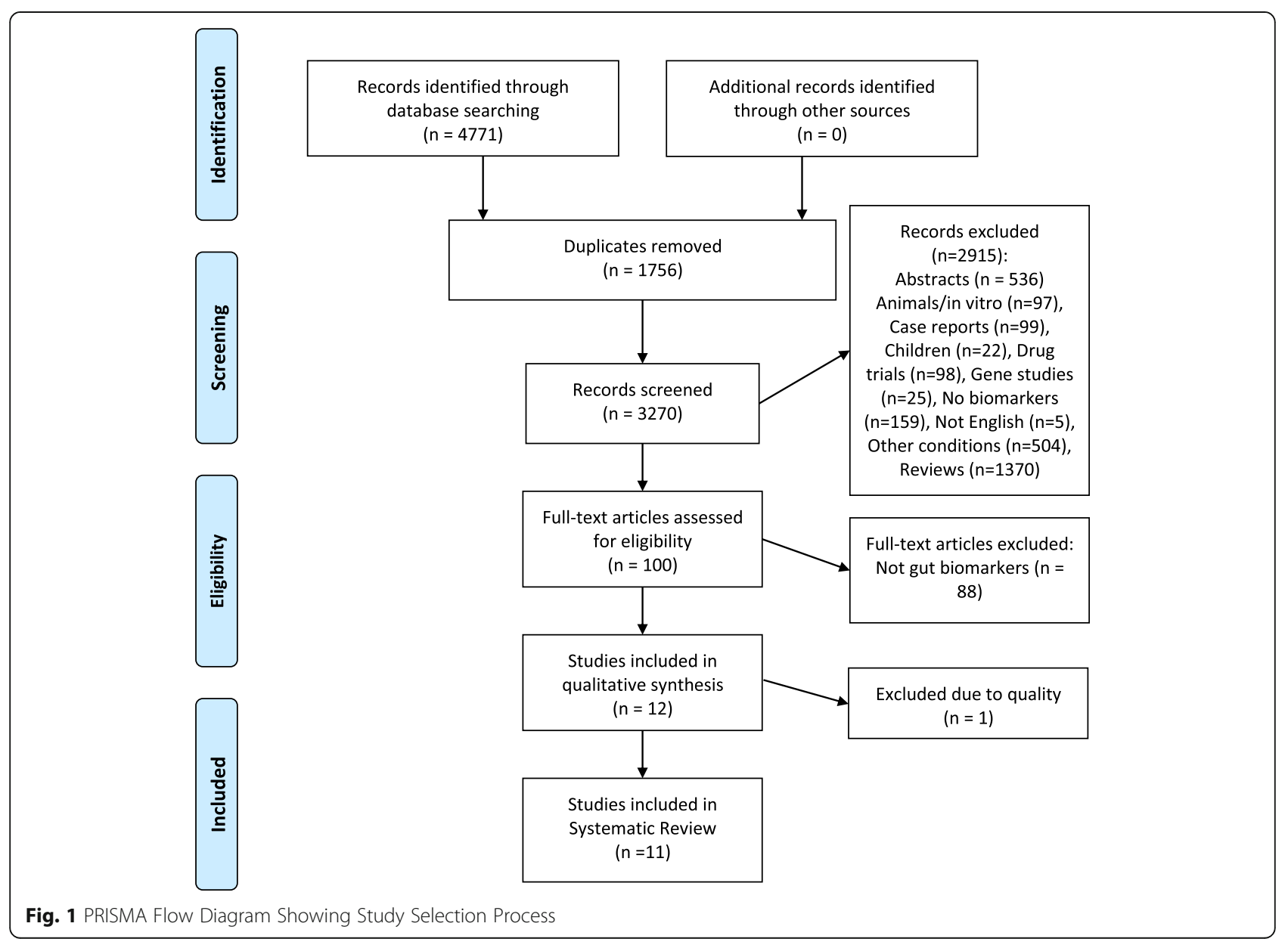


Table 2 Characteristics of 11 papers investigating biomarkers related to the gastrointestinal microbiome in subjects with fibromyalgia

\begin{tabular}{|c|c|c|c|c|c|c|c|c|}
\hline \multirow[t]{2}{*}{ Author (Year) } & \multirow[t]{2}{*}{ Country } & \multicolumn{2}{|l|}{ Cohort } & \multirow[t]{2}{*}{ Study Type } & \multirow{2}{*}{$\begin{array}{l}\text { FMS } \\
\text { criteria }\end{array}$} & \multirow{2}{*}{$\begin{array}{l}\text { Controls } \\
\text { n, Type }\end{array}$} & \multirow[t]{2}{*}{ Biomarker/s } & \multirow{2}{*}{$\begin{array}{l}\text { Quality } \\
\text { Assessment } \\
\%\end{array}$} \\
\hline & & N (\% female) & Age & & & & & \\
\hline Pimentel (2004) [17] & USA & $42(86)$ & $46.6 \pm 0.3$ & Case-control & ACR 1990 & $22 \mathrm{IBS}$ & $\mathrm{SIBO}$ & 53.1 \\
\hline Michalsen (2005) [18] & Germany & $35(91)$ & $\begin{array}{l}52.0 \pm 10.0 \\
51.6 \pm 13.3^{\mathrm{a}}\end{array}$ & Case-control & ACR 1990 & $16 \mathrm{RA}$ & $\begin{array}{l}\text { Stool culture } \\
\text { Stool pH } \\
\text { slgA }\end{array}$ & 56.3 \\
\hline Goebel (2008) [19] & Germany & $40^{c}(80)$ & $48 \pm 11$ & Case-control & ACR 1990 & $\begin{array}{l}57 \mathrm{HC} \\
17 \mathrm{CRPS}\end{array}$ & $\begin{array}{l}\text { H. pyloriBacteria } \\
\text { (serum antibodies) } \\
\text { Intestinal permeability }\end{array}$ & 75.0 \\
\hline Akkaya (2011) [20] & Turkey & $65(100)$ & $36.21 \pm 7.42$ & Case-control & ACR 1990 & $41 \mathrm{HC}$ & H. pylori & 75.0 \\
\hline Olama (2013) [21] & Egypt & $100(100)$ & $33.2 \pm 4.36$ & Case-control & ACR 1990 & $100 \mathrm{HC}$ & H. pylori & 81.3 \\
\hline Rodrigo (2013) [22] & Spain & $104(89)$ & $50 \pm 8^{b}$ & Case-control & ACR 1990 & $125 \mathrm{IBS}$ & H. pylori & 75.0 \\
\hline Gezici (2014) [23] & Turkey & $32(88)$ & $38.5 \pm 8.6$ & Prospective & ACR 1990 & - & H. pylori & 43.8 \\
\hline Malatji (2017) [24] & South Africa & $18(100)$ & 45.5 & Case-control & ACR 1990 & $\begin{array}{l}11 \mathrm{FC} \\
10 \mathrm{MC} \\
41 \mathrm{YC}\end{array}$ & Metabolomics & 75.0 \\
\hline Malatji (2019) [25] & South Africa & $17(100)$ & 45.5 (ns) & Case-control & ACR 1990 & $\begin{array}{l}11 \mathrm{FC} \\
10 \mathrm{MC} \\
41 \mathrm{YC}\end{array}$ & Metabolomics & 75.0 \\
\hline Clos-Garcia (2019) [26] & Spain & $105(70)$ & $52.52 \pm 10.3$ & Case-control & ACR 1990 & $54 \mathrm{HC}$ & $\begin{array}{l}\text { Microbiome } \\
\text { Metabolomics }\end{array}$ & 81.3 \\
\hline Minerbi (2019) [27] & Canada & $77(100)$ & $46 \pm 8$ & Case-control & ACR 2016 & $\begin{array}{l}11 \mathrm{FC} \\
20 \mathrm{HM} \\
48 \mathrm{UC}\end{array}$ & $\begin{array}{l}\text { Microbiome } \\
\text { Metabolites }\end{array}$ & 87.5 \\
\hline
\end{tabular}

Key: ACR American College of Rheumatology; FMS Fibromyalgia; JB Joanna Briggs; $n$ s not stated; IBS irritable bowel syndrome; SIBO small intestinal bacterial overgrowth; RA rheumatoid arthritis; $H C$ healthy controls; CRPS chronic regional pain syndrome; $F C$ family controls; $M C$ matched controls; $Y C$ young controls; $H M$ household members; UC unrelated controls; ${ }^{a}=$ age (SD) of FMS in group $B ;{ }^{b}=$ age of IBS cohort $51 \pm 8 ;{ }^{c}=40$ FMS patients, serology data for 33 .

different data from the same cohort which is included once in the population totals.

Eight papers evaluated markers for specific gut microbes: five reported on Helicobacter pylori [19-23], and are reported as a group. Four described biomarkers of the gut microbiota $[18,19,26,27]$; four explored metagenomics/metabolites or metabolomics [24-27], and three [17-19] reported other biomarkers, such as intestinal permeability. Four studies $[18,19,26,27]$ examined more than one type of biomarker and so are included in each of the appropriate sections below.

A summary of the key information of the 11 included articles is presented in Table 2.

\section{Helicobacter pylori}

Table 3 details results of five studies evaluating H. pylori in patients with fibromyalgia.

Biopsy results from Rodrigo's study also revealed significantly higher rates of intraepithelial lymphocytosis (IEL) (Marsh stage 1) and villous atrophy (Marsh stage 3 ) in the group with fibromyalgia plus IBS, compared to the IBS-only group (56\% vs 16 and $7 \%$ vs $2 \%$, respectively), (both $p<0.001$ ). As a result of this investigation, seven of the 104 patients with fibromyalgia were subsequently diagnosed with coeliac disease [22].

\section{Gastrointestinal microbiota and antibodies}

Four studies are included in this group, as presented in Table 4. In addition to serum antibodies to two gutspecific organisms, Goebel et al., [19] assessed results against measures of intestinal permeability (IP) (see Table 6). Three studies evaluated the microbial composition of faecal specimens, however, all employed different methodology.

\section{Metabolomics/metabolites}

The urinary microbial metabolism data reported in two of the studies included in this review were obtained from the same cohort $[24,25]$. Two other studies evaluated serum markers for a range of metabolites, proteins and gene expression [26, 27], and three compared patients with more than one type of control $[24,25,27]$. These are summarised in Table 5.

Alterations in levels of urine metabolites reported in the first of Malatii's papers [24] were predicted to be associated with gut bacteria. Employing a more targeted approach, the same team later reported the presence of the monosaccharides sorbose, rhamnose and tagatose which are typically not found in human urine [25]. One mechanism proposed by the authors for their presence was bacterial degradation of plant-derived carbohydrates. 
Table 3 Results from 5 Studies Investigating H. pylori

\begin{tabular}{|c|c|c|c|c|c|}
\hline \multirow[t]{2}{*}{ Author (Year) } & \multirow[t]{2}{*}{ Cohort } & \multirow{2}{*}{$\begin{array}{l}\text { Material } \boldsymbol{H} \text {. pylori } \\
\text { marker }\end{array}$} & \multicolumn{3}{|c|}{ H. pylori positive (\%) } \\
\hline & & & $\overline{F M S}$ & Controls & $\bar{p}$-value \\
\hline Goebel (2008) [19] & $\begin{array}{l}33 \text { FMS } \\
17 \text { CRPS } \\
57 \mathrm{HC}\end{array}$ & $\begin{array}{l}\text { Serum antibodies } \\
\text { IgA or IgG }\end{array}$ & 33.0 & HC: NT CRPS: 47.0 & n.s. \\
\hline Akkaya (2011) [20] & $\begin{array}{l}65 \mathrm{FMS} \\
41 \mathrm{HC}\end{array}$ & $\begin{array}{l}\text { Serum antibodies } \\
\operatorname{lgA} \\
\lg G\end{array}$ & $\begin{array}{l}30.8 \\
67.7\end{array}$ & $\begin{array}{l}17.1 \\
43.9\end{array}$ & $\begin{array}{l}0.169 \\
0.025\end{array}$ \\
\hline Olama (2013) [21] & $\begin{array}{l}100 \mathrm{FMS} \\
100 \mathrm{HC}\end{array}$ & $\begin{array}{l}\text { Serum antibodies } \\
\text { IgA } \\
\text { IgG }\end{array}$ & $\begin{array}{l}50.0 \\
68.0\end{array}$ & $\begin{array}{l}24.0 \\
32.0\end{array}$ & $\begin{array}{l}<0.001 \\
<0.001\end{array}$ \\
\hline Rodrigo (2013) [22] & $\begin{array}{l}104 \text { FMS } \\
125 \text { IBS }\end{array}$ & $\begin{array}{l}\text { Gastroduodenal } \\
\text { biopsyH\&E + Giemsa } \\
\text { staining, polyclonal } \\
\text { anti-H. pylori antibody, } \\
\text { microbial cultures }\end{array}$ & 42.0 & 46.0 & n.s. \\
\hline Gezici (2014) [23] & $41^{\#}$ FMS & $\begin{array}{l}\text { Gastric biopsy } \\
\text { Culture }\end{array}$ & 78.0 & - & - \\
\hline
\end{tabular}

Key: \# all had dyspepsia; FMS fibromyalgia; HC healthy controls; CRPS chronic regional pain syndrome; IBS irritable bowel syndrome; NT not tested; NA not reported; $n$.s. not statistically significant.

Clos-Garcia et al. [26] also concluded that some of the altered metabolites, as well as both up- and downstream products, may be bacterial in origin.

\section{Other biomarkers}

Three studies [17-19] outlined in Table 6, evaluated markers not included in the groups above. In Michalsen's study [18], fibromyalgia and rheumatoid arthritis patients were allocated into two separate arms, each of which undertook a different dietary intervention (either a Mediterranean diet or fasting).

Pimentel et al. [17] investigated the prevalence of small intestinal bacterial overgrowth (SIBO) in patients with fibromyalgia, IBS and normal controls. Both peak and area-under-the-curve (AUC) values for hydrogen production where significantly higher in those with fibromyalgia compared to controls both with and without IBS.

Table 4 Results from 4 studies Investigating Gastrointestinal Microbiota Taxa and Antibodies

\begin{tabular}{|c|c|c|c|c|c|}
\hline Author (Year) & $\begin{array}{l}\text { Patients } \\
\text { Controls }\end{array}$ & Material \& Procedure & Results & $\boldsymbol{p}$-value & Other \\
\hline \multirow[t]{2}{*}{ Michalsen (2005) [18] } & $\begin{array}{l}21 \text { FMS } \\
9 \text { RA }\end{array}$ & $\begin{array}{l}\text { Faeces } \\
\text { Culture }\end{array}$ & No differences & n.s & pre- vs post-fasting \\
\hline & $\begin{array}{l}14 \text { FMS } \\
7 \text { RA }\end{array}$ & $\begin{array}{l}\text { Faeces } \\
\text { Culture }\end{array}$ & No differences & n.s & pre- vs post-MedDiet \\
\hline Goebel (2008) [19] & $\begin{array}{l}33 \text { FMS17 CRPS } 57 \\
\text { HC }\end{array}$ & $\begin{array}{l}\text { Serum antibodies } \\
\text { Yersinia or Campylobacter }\end{array}$ & $\begin{array}{l}\text { FMS } 27 \% \text { positive } \\
\text { CRPS } 13 \% \\
\text { HC Not tested }\end{array}$ & NR & $\begin{array}{l}\text { Trend for seropositivity } \\
\text { assoc. with IP (Table 4) }\end{array}$ \\
\hline Minerbi (2019) [27] & $\begin{array}{l}77 \mathrm{FMS} \\
11 \mathrm{FC} \\
20 \mathrm{HM} \\
48 \mathrm{UC}\end{array}$ & $\begin{array}{l}\text { Faeces } \\
\text { 16S rRNA gene } \\
\text { (V5-V6 region) / metagenome }\end{array}$ & $\begin{array}{l}\downarrow \text { Faecalibacterium } \\
\text { and Bacteroides, } \uparrow \\
\text { Intestinimonas, } \\
\text { Flavonifractor, } \\
\text { Butyricoccus } \\
\text { Eisenbergiella and } \\
\text { Enterobacter. }\end{array}$ & $<0.01$ & $\begin{array}{l}\text { Non-significant differences } \\
\text { in sample diversity } \\
\text { Variance FMS vs UC }\end{array}$ \\
\hline $\begin{array}{l}\text { Clos-Garcia (2019) } \\
\text { [26] }\end{array}$ & $\begin{array}{l}105 \mathrm{FMS} \\
54 \mathrm{HC}\end{array}$ & $\begin{array}{l}\text { Faeces } \\
16 \mathrm{~S} \text { rDNA microbiome(V3-V4 } \\
\text { region) }\end{array}$ & $\begin{array}{l}\text { FMS: Absent families: } \\
\text { Bifidobacteriaceae } \\
\text { and Bacteroidales } \uparrow \\
\text { Dorea, Roseburia, } \\
\text { Alistipes, Papillibacter, } \\
\text { Subdoligranulum } \downarrow \\
\text { Bacteroides, } \\
\text { Bifidobacterium, } \\
\text { Eubacterium, Clostridium }\end{array}$ & $\begin{array}{l}\text { All } p \leq \\
0.05\end{array}$ & $\begin{array}{l}\text { Controls had higher } \\
\text { diversity }\end{array}$ \\
\hline
\end{tabular}


Table 5 Results from 3 studies (4 papers) Investigating Metabolites and Metabolomics

\begin{tabular}{|c|c|c|c|c|}
\hline Author (Year) & $\begin{array}{l}\text { Subjects } \\
\text { Controls }\end{array}$ & $\begin{array}{l}\text { Material } \\
\text { Biomarker }\end{array}$ & FMS Subjects & $\boldsymbol{P}$ value for diff \\
\hline Malatji (2017) [24] & $\begin{array}{l}18 \text { FMS11 } \\
\text { FC10 MC41 YC }\end{array}$ & $\begin{array}{l}\text { UrineNMR } \\
\text { metabolome }\end{array}$ & $\begin{array}{l}\text { Compared to YC } \\
\uparrow \text { hippuric acid } \\
\uparrow \text { succinic acid } \\
\uparrow \text { lactic acid } \uparrow \\
2 \text {-Hydroxyisobutyric } \\
\text { acid }\end{array}$ & $\begin{array}{l}p=0.0966(\mathrm{~ns}) \\
p=0.0001(\mathrm{MW}) \\
p=0.0044 \\
p=0.0001\end{array}$ \\
\hline Malatji (2019) [25] & $\begin{array}{l}17 \text { FMS11 } \\
\text { FC10 MC41 YC }\end{array}$ & $\begin{array}{l}\text { UrineGC-MS } \\
\text { metabolome }\end{array}$ & $\begin{array}{l}\uparrow 14 \text { metabolites c.f. } \\
\text { MC } \uparrow \text { 4-hydroxyisobutyric } \\
\text { acid c.f. MC \& YC } \\
\uparrow \text { arabinose c.f. MC }\end{array}$ & $\begin{array}{l}\text { All }<0.001 \\
\text { (MW \& BF) } \\
p=0.00109\end{array}$ \\
\hline Minerbi (2019) [27] & $\begin{array}{l}77 \text { FMS11 FC20 } \\
\text { HM48 UC }\end{array}$ & $\begin{array}{l}\text { Serum } \\
\text { Metabolites }\end{array}$ & $\begin{array}{l}\text { Compared to UC: } \\
\uparrow \text { serum butyrate } \downarrow \text { serum } \\
\text { propionic acid } \\
\downarrow \text { isobutyric acid }\end{array}$ & $\begin{array}{l}p=0.005 p=0.006 \\
p=0.056 \text { (ns) }\end{array}$ \\
\hline Clos-Garcia (2019) [26] & 105 FMS54 HC & $\begin{array}{l}\text { Serum } \\
\text { Metabolome }\end{array}$ & 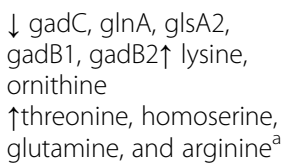 & $\begin{array}{l}p<0.05 \\
p<0.05 \\
p<0.001\end{array}$ \\
\hline
\end{tabular}

Key: FMS Fibromyalgia; NMR nuclear magnetic resonance spectrometry; GC-MS gas chromatography-mass spectrometry: HC healthy controls; FC family controls; $M C$ matched controls; YC young controls; HM household members; UC unrelated controls; c.f. compared to; MW Mann Whitney test; BF Bonferroni-Holm test; $n$ s not significant; gad glutamate decarboxylase; gln glutamine synthetase; gls glutaminase: ${ }^{a}$ all identified as likely of bacterial origin.

Both small intestinal and gastroduodenal permeability was evaluated in Goebel's study [19] employing lactulose-mannitol recovery testing. Follow-up data collected in the week after testing, while not available for all participants, revealed 2 days of moderate-to-severe diarrhoea in 13 of the 31 subjects.

\section{Gut biomarkers and interventions associated with fibromyalgia symptoms}

Studies exploring the relationship between $H$. pylori and fibromyalgia were conflicting. Akkaya's study found no differences in regards to any of the clinical features evaluated [20], whereas Olama et al., described significant associations between $H$. pylori immunoglobulin-G (IgG) -positive patients and disease markers, including: postexertion pain, morning stiffness, confusion, mood, tension headache, sleep disturbance, dyscognition, changes in appetite and fatigue (all $p<0.05$ ) [21]. Gezici's group reported a significant reduction in pain, as evaluated by the number of tender points, following $H$. pylori eradication $(p<0.001)$ [23].

A significant association between the differential abundance of several taxa and some indices of the 2016 ACR Fibromyalgia criteria (such as pain intensity, widespread pain index (WPI), dyscognition), and quality of life scores (including fatigue) was reported by Minerbi's group (all $p<0.05$ ). Some operational taxonomic units were found to be inversely related to many of the same

Table 6 Results From 3 Studies Investigating Other Gut-Related Markers

\begin{tabular}{|c|c|c|c|c|c|}
\hline \multirow{2}{*}{$\begin{array}{l}\text { Author } \\
\text { (Year) }\end{array}$} & \multirow[t]{2}{*}{ Cohort } & \multirow{2}{*}{$\begin{array}{l}\text { Material / } \\
\text { Biomarker }\end{array}$} & \multicolumn{2}{|l|}{ Results } & \multirow[t]{2}{*}{$\boldsymbol{p}$-value for diff } \\
\hline & & & FMS & Controls & \\
\hline $\begin{array}{l}\text { Pimentel } \\
(2004) \text { [17] }\end{array}$ & $\begin{array}{l}42 \mathrm{FMS}^{\mathrm{a}} \\
111 \mathrm{IBS} \\
15 \mathrm{HC}\end{array}$ & Breath(SIBO) & $100 \%$ & $\begin{array}{l}\text { IBS } 84 \% \\
\text { HC 20\% }\end{array}$ & $\begin{array}{l}<0.05 \\
<0.0001\end{array}$ \\
\hline \multirow[t]{2}{*}{$\begin{array}{l}\text { Michalsen } \\
\text { (2005) [18] }\end{array}$} & 21 FMS9 RA & $\begin{array}{l}\text { StoolpH \& } \\
\text { slgAfollowing } \\
\text { fasting }\end{array}$ & & $\begin{array}{l}\text { No differences } \\
\text { between FMS } \\
\text { vs RA groups } \\
\text { or with different } \\
\text { interventions }\end{array}$ & n.s. \\
\hline & 14 FMS7 RA & $\begin{array}{l}\text { StoolpH \& } \\
\text { slgAfollowing } \\
\text { MedDiet }\end{array}$ & & & n.s. \\
\hline $\begin{array}{l}\text { Goebel } \\
\text { (2008) [19] }\end{array}$ & $\begin{array}{l}40 \text { FMS } \\
17 \text { CRPS } \\
57 \mathrm{HC}\end{array}$ & $\begin{array}{l}\text { UrineGD } \\
\text { permeabilitySI } \\
\text { permeability }\end{array}$ & $32.5 \% 37.5 \%$ & $\begin{array}{l}\text { CRPS } 35.3 \%, \mathrm{HC} \\
5 \% \text { CRPS } 17.6 \% \\
\text { HC 0\% }\end{array}$ & $<0.0001^{b}<0.0002^{\&}$ \\
\hline
\end{tabular}

Key: ${ }^{a}=22$ (54\%) had IBS; ${ }^{\mathrm{b}}=p$-value compared to controls; FMS Fibromyalgia; CRPS chronic regional pain syndrome; $H C$ healthy controls; GD gastroduodenal; SI small intestine; IBS irritable bowel syndrome; RA rheumatoid arthritis; MedDiet Mediterranean Diet; SIBO small intestinal bacterial overgrowth; n.s. not significant. 
indicators in unrelated controls [27]. Genus-level composition of the gut microbiome weakly correlated to pain indicators in Clos-Garcia's report, with the strongest correlations in micro ribonucleic acid (miRNA) data, followed by serum proteins and metabolomics [26]. Malatji et al. (2017) described specific combinations of metabolites (creatine \& succinic acid $+/$ - taurine) relating to pain scores and loss of energy [24]. In spite of indicating that $88 \%$ of their small cohort had some degree of gastrointestinal dysfunction, possibly classified as IBS, details were not described; nor was any attempt made to relate digestive symptoms to the measured metabolites [25].

Pain scores correlated significantly with both peak and AUC hydrogen gas production $(\mathrm{r}=0.42, p<0.01$ and $\mathrm{r}=$ $0.37, p<0.05)$ on breath testing by Pimentel's group [17]. Treatment of SIBO resulted in significant reductions in pain $(p<0.05)$. A non-significant improvement in clinical measures was described in those patients following the fasting regime in Michalsen's study [18], and Goebel reported no association between IP and the pain of either chronic regional pain syndrome (CRPS) or fibromyalgia [19].

\section{Discussion}

We set out to systematically evaluate the literature reporting data associated with the gut microbiota in people with fibromyalgia. The review identified five broad areas of research, but to date no single gutfibromyalgia biomarker has been validated. Some studies demonstrated variability in markers associated with the gut microbiota in patients with fibromyalgia compared to healthy controls [24].

A wide range of research methods were detected and lack of control for factors which may impact the biomarkers being investigated was common. This included failure to measure dietary patterns, smoking and drug use. Importantly, of the included studies that evaluated the composition of the gut microbiome, the methods used were different, making comparisons problematic. Some statistically significant differences were reported, but due to the high degree of variability in both the methods and markers evaluated, and the presence of important confounding factors, it is difficult to draw any strong conclusions.

\section{Helicobacter pylori}

While several papers reported a relationship between $H$. pylori and fibromyalgia the results are inconsistent. This is probably due to a combination of different identification methods and potential confounders, such as the retention of patients in the control group with CRPS who met fibromyalgia criteria [19].
None of the included studies utilised stool antigen or 13C-urea breath tests, and two [22, 23] performed culture following biopsy. Each of these are more reliable than serology for $H$. pylori diagnosis [28].

Rodrigo et al., [22] described H. pylori at similar rates in patients with IBS regardless of fibromyalgia status. They also found coeliac disease (CD) in fibromyalgic patients at seven times the population rate and more than double that reported in fibromyalgia elsewhere [29]. A 2012 study of $376 \mathrm{CD}$ patients demonstrated $22 \%$ met the 1990 ACR criteria for fibromyalgia [30] suggesting a bidirectional relationship. In addition to its association with CD and non-coeliac gluten sensitivity [31], IEL has also been observed in $H$. pylori infections [32], although other work has refuted this relationship [33]. No other study included in this review evaluated subjects for $C D$ and neither CD nor IEL were in our search terms.

All subjects in Gezici's Turkish study had fibromyalgia and dyspepsia; $78 \%$ were positive for $H$. pylori [23], similar to the overall prevalence in that country [34]. Cytotoxin-associated gene A (CagA)-positive strains of H. pylori are associated with a higher risk of dyspepsia [35], but none of the studies included in this review evaluated virulence factors.

In summary, the studies provide weak evidence that $H$. pylori may play a role in the symptomology of fibromyalgia, and while the exact relationship is uncertain, the improvement seen in pain scores just 3 weeks after antibiotic treatment of $H$. pylori [23] warrants a systematic and rigourous investigation.

\section{Gut microbiota}

With rapid developments in microbiome technology over the last two decades, it is not surprising our review identified a diverse set of methodological approaches employed in the assessment of antimicrobial communities. In 2005, bacterial culture was the accepted procedure as DNA sequencing was in its infancy.

Michalsen's study [18] demonstrated no differences in the microbiota, however, this finding is limited by an absence of a healthy control group. Additionally, fibromyalgia and rheumatoid arthritis (RA) commonly coexist [36], and it is unclear whether participants with fibromyalgia were screened for RA.

A higher prevalence of positive antibodies to either Yersinia enterocolitica or Campylobacter jejuni (data not separated) in subjects with fibromyalgia compared to those with CRPS is difficult to interpret [19]. While these organisms commonly coexist, double-positivity for H. pylori plus C. jejuni tends to be low [37] and H.pylori, which may be protective against infection-induced diarrhoeal disease [38], was high in this cohort. Other factors, including use of $H$. pylori serology, absent data for healthy controls, and seasonal variability of $C$. jejuni 
infection [37, 39], create further limitations to both the interpretation and generalisability of these findings.

Imbalances in several genera were evident in the gut microbiota data reported by both Minerbi and ClosGarcia [26, 27] (Table 4). Differences in sample collection protocols, the regions of amplification and the sequencing platforms makes comparability difficult.

In addition to assessing the microbiome, Minerbi et al. [27] evaluated relationships with a range of other variables, including age, diet, drugs and physical activity. A particular strength of the study was the inclusion of genetic (first-degree relatives), environmental (household cohabitants) and normal (non-related, not cohabiting) controls and a dietary assessment for comparison between groups.

Several significant $(p<0.05)$, positive correlations were reported between fibromyalgia symptoms and some taxa. Differences in the microbiota were associated with the diagnosis and symptoms of fibromyalgia. Of note, Bacteroides spp. was positively correlated with total symptom score on the Fibromyalgia Impact Questionnaire (FIQ) and the 2016 ACR diagnostic criteria. Increased abundance of Parabacteroides merdae and a nonsignificant increase in Akkermansia muciniphila was also reported. These species appear to function synergistically, resulting in lower faecal gamma-glutamylation activity, with a subsequent increase in hippocampal gamma-Aminobutyric acid (GABA): glutamate [40]. While the relevance of this in fibromyalgia is unclear, and an in depth discussion is outside the scope of this review, it is interesting that glutamate, which functions as an excitatory neurotransmitter and plays a role in pain signaling $[41,42]$ has been reported at higher levels in the insula [43] and in the interstitial compartment of muscle of fibromyalgics [44]. Altered brain levels of glutamate + glutamine have been associated with increased pain sensitivity [45] and other research, identified lower levels of the neurotransmitter GABA in the same area of the brain [46].

Clos-Garcia et al. [26] used quantitative polymerase chain reaction (qPCR) to determine bacterial gene expression related to glutamate metabolism and despite finding five out of six glutamate degrading genes at significantly higher levels in fibromyalgics than controls (which would be expected to result in less glutamate), higher serum levels of glutamate were found in the fibromyalgia group. While this appears contradictory, the higher serum glutamate is consistent with other data reporting a role for glutamate in the central nervous system (CNS) [47] and in pain signaling [41]. The bacteria involved in glutamate and GABA metabolism in these two studies were different: Bifidobacterium and Lactobacillus in Clos-Garcia's study [26], and Akkermansia muciniphila and Parabacteroides spp., in Minerbi's [27].
These differences are likely to be attributable to the region of the genome sequenced. Clos-Garcia's group also described a "discrete" lower bacterial diversity in their patients, and higher abundance of several butyrate producers, congruent with findings of higher levels of the butyrate in the serum.

A high rate of drug use, both prescription and complementary medicines, was reported in Clos-Garcia's study. Data provided in their Supplemental Table 1, detailed 169 agents, including several with psychotropic and CNS effects. Antidepressants, benzodiazepines, antiepileptics and gabapentin and were used by $76,66,28$ and $10 \%$ of patients respectively and $23 \%$ were current smokers. Minerbi's group [27] also collected information regarding drug use and smoking status, but little attention was given to these as confounders, nor was detail regarding the type, or extent of drug use or smoking provided. Drugs of many kinds may impact gut bacteria and their metabolism, and vice-versa: smoking is associated with an altered gut microbial profile [48] and the Ruminococcus genus (which was overexpressed in Clos-Garcia's patient group) can impact antidepressant metabolism, drugs which also alter the gut microbiota [49].

The understanding of the wide-reaching role of gut bacteria in a plethora of metabolic processes and health conditions has advanced significantly in recent years. The advent of deep sequencing of the microbiome has enabled a new era of discovery which is rapidly evolving. Due to the limited number of studies evaluating the composition of the gastrointestinal microbiota in our results, the heterogeneity of techniques used, variance in findings, and issues around drug use, it is difficult to draw any firm conclusions regarding microbiome alterations in this patient population. This Pandora's box is of intricate complexity [50], such that meaningful results would possibly be best obtained by studying these factors in a much larger, drug-naïve cohort. To date, no extensive analysis has been undertaken to simultaneously evaluate the composition of the gastrointestinal tract microbiota, its metabolites, luminal neurotransmitters and brain neurochemistry in people with fibromyalgia. Future studies should consider such analyses.

\section{Metabolomics}

Several variations in metabolomic markers suggest altered microbial metabolism, but these are not consistent across the studies. The previously identified problems regarding the impact of drug intake and different dietary patterns in the patient populations confounds results.

Alterations in levels of short chain fatty acids (SCFA) suggest a role for altered bacterial populations, though few, and at times conflicting, associations were reported. Higher serum butyrate was reported by Minerbi, which is consistent with increased urinary butyrate seen in 
Malatji's study but is at odds with the lower expression of butyrate-producers reported by both Minerbi and Clos-Garcia. Interestingly, lower levels of butyrateproducing bacteria are reported in IBS [51], which may be a reflection of its roles in regulating the colonic mucosa, intestinal motility and modulating visceral hypersensitivity [52]. As such, these butyrate alterations in fibromyalgia warrant further investigation.

It is unclear if the elevated urinary lactate reported by Malatji study [53] was the L-isomer (which is endogenously produced in muscle metabolism), the D-form, which is primarily from exogenous (bacterial) sources [54] or both. D-lactic acidosis is a serious condition, associated with metabolic acidosis and encephalopathy. While no evidence exists that sub-clinical levels of Dlactate may contribute to other conditions, Rao et al. [55] maintain that mild cognitive symptoms produced by oral administration of glucose are attributable to the intestinal production of D-lactate. Dyscognition is a common symptom in fibromyalgia [56] and Malatji's group did not report correlations in this domain with lactate.

The authors predicted succinate to be human in origin, as it is a metabolite of the Krebs Cycle [24]. However, gut bacteria also produce succinate from fibre, which is subsequently metabolised to propionate [57]. How the origin of succinate was determined to be human is unclear.

A notable strength of the work by Malatji et al., is the range of controls, including family members and cohabitants, allowing the researchers to consider shared factors that may influence results. However, scant information on drug use was provided in their reports [24, 25], nor was this controlled for, which is a significant limitation.

The overall diversity of gut microbiota, various influences on it and the resultant metabolites within any one population group present significant research challenges. The per os intake of any substrate or metabolite may increase populations of any organism able to consume it [42], and as such, measures of metabolites only give part of the picture. The use of both metagenomics and metatranscriptonomics in future studies may illuminate this issue.

\section{Other biomarkers}

\section{Intestinal Hyperpermeability}

Goebel et al's findings suggesting increased IP in both fibromyalgia and CRPS should be interpreted with caution [19]. The study protocol permitted participants to take non-steroidal anti-inflammatory drugs (NSAIDs) up to 48 $\mathrm{h}$ before and aspirin until commencing the study. Use of both these agents is associated with increased IP $[58,59]$. Accordingly, higher levels of IP could reasonably be expected to occur secondary to use of the medications, but neither actual drug intake relative to test commencement, nor other factors known to be associated with altered IP were reported. Furthermore, Goebel's study solution contained $10 \mathrm{~g}$ lactulose, $5 \mathrm{~g}$ mannitol and $20 \mathrm{~g}$ sucrose, and as a solution containing a much lower dose of lactulose and mannitol ( $5 \mathrm{~g}$ and $1 \mathrm{~g}$ respectively) can arrive in the colon within $2 \mathrm{~h}$ [60], the reliability of prediction of small intestinal permeability within this time-frame requires further investigation. Notably absent was a discussion about diarrhoea reported in fibromyalgia patients following this test [19], which could be related to osmotic effects of the saccharide load, or fermentation of same by bacteria. While a recent systematic review found relationships between increased IP and several chronic conditions [61], the validity of sugar-recovery tests as measures of IP and the applicability of increased IP to aberrations in human health beyond $\mathrm{CD}$ and inflammatory bowel diseases remains uncertain [62].

We commented previously on succinate, one of the metabolites contributing to differentiation of fibromyalgics and healthy controls, reported by Malatji (2017) [24]. Additionally, elevated circulating succinate [24] has been reported in patients with SIBO [63], IBS [64] H. pylori infection [65] and is associated with increased IP [66], indicating a gut-mediated inflammatory process. Whether any of these connections can be made for fibromyalgia patients with increased IP requires investigation.

\section{Small intestinal bacterial overgrowth}

The association between a positive hydrogen breath test and fibromyalgia [17] (Table 5), should be interpreted within the context of the limitations of the test, testing procedures and diagnostic criteria used. The authors regarded a normal breath test as having no rise in hydrogen or methane before 90 min of administration of lactulose, with " $a$ definitive rise never more than 20 ppm" over $3 \mathrm{~h}$ of testing. Accordingly, most subjects would be expected to meet SIBO criteria, as lactulose is expected to initiate fermentation on arrival in the colon, which typically occurs within 100 mins [67]. Current criteria specify a diagnostic rise should occur before $90 \mathrm{~min}$ [68]. While hydrogen and methane were both measured in Pimentel's 2004 study [17], test data was not tabulated and only hydrogen results were presented and discussed.

An association between fibromyalgia and SIBO was reported by Pimentel's group in 2001 [69], a paper not included in our review due to unclear criteria for the diagnosis of both fibromyalgia and SIBO.

Fibromyalgics present with constipation at up to double the rate of those with diarrhoea [11, 70], which correlates with severity of fibromyalgia symptoms [70]. Constipation is associated with higher methane production [71], yet both Pimentel's studies reported elevations in hydrogen gas $[17,69]$. Despite the 2004 study being remarkable for 
its $100 \%$ detection rate of SIBO in fibromyalgics, to our knowledge no further studies have confirmed this relationship.

\section{Strengths \& Limitations}

A significant strength of this review is our requirement for clear and accepted criteria for the diagnosis of fibromyalgia. However, methodical differences, inconsistency in the testing methods used, inappropriate drug use and the inclusion of controls with diseases that were unaccounted pose limitations to our findings.

Oxidative stress markers, neurotransmitters or amino acids associated with pain signaling and neurological function were not included in our search terms. As alterations in several neurotransmitters, including serotonin and glutamate, have been implicated in fibromyalgia $[7,41]$ and bacteria may be involved in their synthesis [72], it could be argued that these terms should have been included. While some papers reporting these were picked up in our search, we determined that, as neurochemicals were not targeted in our search terms, the studies identified would not provide adequate substance for inclusion in a comprehensive review focusing on biomarkers associated with gastrointestinal dysfunction.

Despite these limitations and the heterogeneity of the studies included, preliminary findings suggest that gastrointestinal microbiome-targeted interventions may improve clinical and/or laboratory measures related to the symptoms of fibromyalgia.

\section{Conclusions}

The findings of this review suggest the relationship between the gut microbiome and the pathophysiology of fibromyalgia is a largely underexplored area. Despite the limitations of the included studies, there are several indications that associations between the composition and metabolism of the gastrointestinal microbiota and fibromyalgia may exist. As such, well-designed studies that employ the latest technology and accepted diagnostic testing practices while accounting for confounding factors are warranted.

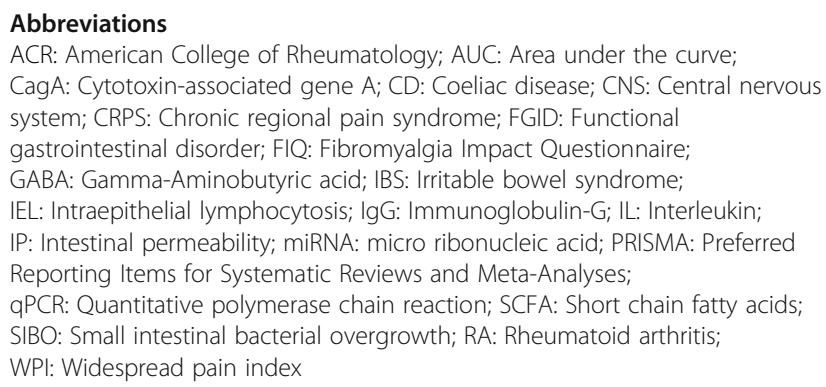

\section{Acknowledgements}

Thanks to Dr. Yulia Ulyannikova for guidance in structuring and conducting the systematic review.

\section{Authors' contributions}

SE co-designed the study, conducted the searches, sorted the results and was the major contributor in drafting the manuscript. JAH co-designed the study, assisted in interpretation of the data, and edited the manuscript. SPM assisted in interpreting the data and editing the manuscript. JEH codesigned the study, contributed to interpretation of data, was a major contributor in writing the manuscript. All authors read and approved the final manuscript.

\section{Funding}

None.

\section{Availability of data and materials}

Data sharing not applicable to this article as no datasets were generated. All datasets reviewed in this article are cited in the results section.

Ethics approval and consent to participate

Not applicable.

\section{Consent for publication}

Not applicable.

\section{Competing interests}

The authors declare that they have no competing interests.

\section{Author details}

${ }^{1}$ Faculty of Medicine and Health, School of Pharmacy, The University of Sydney, Sydney, New South Wales, Australia. ${ }^{2}$ College of Health and Medicine, University of Tasmania, Hobart, Tasmania, Australia. ${ }^{3}$ NatMed Research Unit, Division of Research, Southern Cross University, Lismore, New South Wales, Australia.

Received: 25 January 2020 Accepted: 11 March 2020

Published online: 20 March 2020

\section{References}

1. Inanici F, Yunus MB. History of fibromyalgia: past to present. Curr Pain Headache Rep. 2004;8(5):369-78.

2. Macfarlane GJ, Kronisch C, Dean LE, Atzeni F, Hauser W, Fluss E, Choy E, Kosek E, Amris K, Branco J, et al. EULAR revised recommendations for the management of fibromyalgia. Ann Rheum Dis. 2017;76(2):318-28.

3. Marques AP, AdSdE S, Berssaneti AA, Matsutani LA, SLK Y. Prevalence of fibromyalgia: Literature review update. Rev Bras Reumatol Eng Ed. 2017; 57(4):356-63.

4. Lacasse A, Bourgault $P$, Choinière M. Fibromyalgia-related costs and loss of productivity: a substantial societal burden. BMC Musculoskelet Disord. 2016; 17:168.

5. Arnold LM, Bennett RM, Crofford LJ, Dean LE, Clauw DJ, Goldenberg DL Fitzcharles M-A, Paiva ES, Staud R, Sarzi-Puttini P, et al. AAPT diagnostic criteria for fibromyalgia. J Pain. 2019;20(6):611-28.

6. Cassisi G, Sarzi-Puttini P, Cazzola M. Chronic widespread pain and fibromyalgia: Could there be some relationship with infections and vaccinations? Clin Exp Rheumatol. 2011;29(6 Suppl. 69):S118-26.

7. Becker $\mathrm{S}, \mathrm{Sch}$ weinhardt P. Dysfunctional neurotransmitter systems in fibromyalgia, their role in central stress circuitry and pharmacological actions on these systems. Pain Res Treat. 2012;2012. Article ID:741746.

8. Albrecht DS, Forsberg A, Sandstrom A, Bergan C, Kadetoff D, Protsenko E, Lampa J, Lee YC, Hoglund CO, Catana C, et al. Brain glial activation in fibromyalgia - a multi-site positron emission tomography investigation. Brain Behav Immun. 2019;75:72-83.

9. Grayston R, Czanner G, Elhadd K, Goebel A, Frank B, Üçeyler N, Malik RA, Alam U. A systematic review and meta-analysis of the prevalence of small fiber pathology in fibromyalgia: implications for a new paradigm in fibromyalgia etiopathogenesis. Semin Arthritis Rheum. 2019;48(5):933-40.

10. Giacomelli C, Sernissi F, Rossi A, Bombardieri S, Bazzichi L. Biomarkers in fibromyalgia: A review. Curr Biomarker Find. 2014;4:35-41.

11. Erdrich S, Hawrelak J, Myers S, Harnett J: A systematic review of the association between fibromyalgia and functional gastrointestinal disorders (FGID). [under review] 2020.

12. Casén C, Vebø HC, Sekelja M, Hegge FT, Karlsson MK, Ciemniejewska E, Dzankovic S, Frøyland C, Nestestog R, Engstrand L, et al. Deviations in 
human gut microbiota: a novel diagnostic test for determining dysbiosis in patients with IBS or IBD. Aliment Pharmacol Ther. 2015:42(1):71-83.

13. Sperber AD, Atzmon $Y$, Neumann $L$, Weisberg I, Shalit $Y$, Abu-Shakrah M, Fich A, Buskila D. Fibromyalgia in the irritable bowel syndrome: studies of prevalence and clinical implications. Am J Gastroenterol. 1999;94(12):3541-6.

14. Whitehead WE, Palsson O, Jones KR. Systematic review of the comorbidity of irritable bowel syndrome with other disorders: what are the causes and implications? Gastroenterology. 2002;122(4):1140-56.

15. Moher D, Liberati A, Tetzlaff J, Altman DG, The PG. Preferred reporting items for systematic reviews and meta-analyses: the PRISMA statement. PLoS Med. 2009;6(7):e1000097.

16. Moola S, Munn Z, Tufanaru C, Aromataris E, Sears K, Sfetcu R, Currie M, Qureshi RPM, Lisy K, et al. Systematic reviews of etiology and risk In: Aromataris E, Munn Z, editors. Joanna Briggs Institute Reviewer's Manual. Adelaide: The Joanna Briggs Institute; 2017. Available from https:// reviewersmanual.joannabriggs.org/.

17. Pimentel M, Wallace D, Hallegua D, Chow E, Kong Y, Park S, Lin HC. A link between irritable bowel syndrome and fibromyalgia may be related to findings on lactulose breath testing. Ann Rheum Dis. 2004;63:450-2.

18. Michalsen A, Riegert M, Ludtke R, Backer M, Langhorst J, Schwickert M, Dobos GJ. Mediterranean diet or extented fasting's influence on changing the intestinal microflora, immunoglobulin A secretion and clinical outcome in patients with rheumatiod arthritis and fibromyalgia: An observational study. BMC Complement Altern Med. 2005;5(22). https://doi.org/10.1186/ 1472-6882-5-22.

19. Goebel A, Buhner S, Schedel R, Lochs H, Sprotte G. Altered intestinal permeability in patients with primary fibromyalgia and in patients with complex regional pain syndrome. Rheumatology. 2008;47(8):1223-7.

20. Akkaya N, Akkaya S, Polat $Y$, Turk M, Turk T, Turhal E, Sahin F. Helicobacter pylori seropositivity in fibromyalgia syndrome. Clin Rheumatol. 2011;30(1):43-9.

21. Olama SM, El-Arman M. Helicobacter pylori in Egyptian patients with fibromyalgia syndrome. Egypt Rheumatologist. 2013;35(3):167-73.

22. Rodrigo L, Blanco I, Bobes J, de Serres FJ. Remarkable prevalence of coeliac disease in patients with irritable bowel syndrome plus fibromyalgia in comparison with those with isolated irritable bowel syndrome: a casefinding study. Arthritis Res Ther. 2013;15:R201.

23. Gezici E, Alpayci M, Ozkan Y, Kucuk ME, Unver H, Hiz O. The effects of helicobacter pylori eradication on the number of tender points, sleep quality, depression, and anxiety in patients with fibromyalgia. Arch Rheumatol. 2014;29(3):151-4.

24. Malatji BG, Meyer H, Mason S, Engelke UFH, Wevers RA, van Reenen M, Reinecke CJ. A diagnostic biomarker profile for fibromyalgia syndrome based on an NMR metabolomics study of selected patients and controls. BMC Neurol. 2017;17:88.

25. Malatji BG, Mason S, Mienie LJ, Wevers RA, Meyer H, van Reenen M, Reinecke CJ. The GC-MS metabolomics signature in patients with fibromyalgia syndrome directs to dysbiosis as an aspect contributing factor of FMS pathophysiology. Metabolomics. 2019;15:54.

26. Clos-Garcia M, Andres-Marin N, Fernandez-Eulate G, Abecia L, Lavin JL, van Liempd S, Cabrera D, Royo F, Valero A, Errazquin N, et al. Gut microbiome and serum metabolome analyses identify molecular biomarkers and altered glutamate metabolism in fibromyalgia. EBioMedicine. 2019;46:499-511.

27. Minerbi A, Gonzalez E, Brereton NJB, Anjarkouchian A, Dewar K, Fitzcharles MA, Chevalier S, Shir Y. Altered microbiome composition in individuals with fibromyalgia. Pain. 2019;00:1-14.

28. Kayali S, Aloe R, Bonaguri C, Gaiani F, Manfredi M, Leandro G, Fornaroli F, Di Mario F. De' Angelis GL: non-invasive tests for the diagnosis of helicobacter pylori: state of the art. Acta Biomed. 2018;89(Suppl 8):58-64.

29. McKenna T, Mohabbat A, Salonen B, Raslau D, Luedtke C. Prevalence of celiac disease in fibromyalgia patients: The Mayo Clinic experience. J Gen Intern Med. 2017:32(2 Suppl. 1):S287.

30. Antonova V, Kopishinskaya S, Gustov A, Repin A. Fibromyalgia in celiac disease patients. Eur J Neurol. 2012;19(Suppl.1):628.

31. Talley NJ, Walker MM. Celiac disease and nonceliac gluten or wheat sensitivity: the risks and benefits of diagnosis. JAMA Intern Med. 2017; 177(5):615-6.

32. Brown I, Mino-Kenudson M, Deshpande V, Lauwers GY. Intraepithelial lymphocytosis in architecturally preserved proximal small intestinal mucosa: an increasing diagnostic problem with a wide differential diagnosis. Arch Pathol Lab Med. 2006;130(7):1020-5.
33. Simondi D, Ribaldone DG, Bonagura GA, Foi S, Sapone N, Garavagno M, Villanacci V, Bernardi D, Pellicano R, Rizzetto M, et al. Helicobacter pylori in celiac disease and in duodenal intraepithelial lymphocytosis: active protagonist or innocent bystander? Clin Res Hepatol Gastroenterol. 2015; 39(6):740-5.

34. Ozaydin N, Turkyilmaz SA, Cali S. Prevalence and risk factors of helicobacter pylori in Turkey: a nationally-representative, cross-sectional, screening with the ${ }^{13} \mathrm{C}$-urea breath test. BMC Public Health. 2013;13:1215.

35. Meng W-P, Wang Z-Q, Deng J-Q, Liu Y, Deng M-M, Lü M-H. The role of H. pylori CagA in regulating hormones of functional dyspepsia patients. Gastroenterol Res Pract, Article ID. 2016:7150959.

36. Gist AC, Guymer EK, Eades LE, Leech M, Littlejohn GO. Fibromyalgia remains a significant burden in rheumatoid arthritis patients in Australia. Int J Rheum Dis. 2018;21(3):639-46.

37. Zautner AE, Johann C, Strubel A, Busse C, Tareen AM, Masanta WO, Lugert R, Schmidt-Ott R, Groß U. Seroprevalence of campylobacteriosis and relevant post-infectious sequelae. Eur J Clin Microbiol Infect Dis. 2014;33(6):1019-27.

38. Cohen D, Shoham O, Orr N, Muhsen K. An inverse and independent association between helicobacter pylori infection and the incidence of shigellosis and other diarrheal diseases. Clin Infect Dis. 2012;54(4):e35-42.

39. Kovats RS, Edwards SJ, Charron D, Cowden J, D'Souza RM, Ebi KL, Gauci C, Gerner-Smidt P, Hajat S, Hales S, et al. Climate variability and campylobacter infection: an international study. Int J Biometeorol. 2005;49(4):207-14.

40. Olson CA, Vuong HE, Yano JM, Liang QY, Nusbaum DJ, Hsiao EY. The gut microbiota mediates the anti-seizure effects of the ketogenic diet. Cell. 2018;173:1728-41.

41. Pyke LT, Osmotherly GP, Baines GS. Measuring glutamate levels in the brains of fibromyalgia patients and a potential role for glutamate in the pathophysiology of fibromyalgia symptoms: a systematic review. Clin J Pain. 2017;33(10):944-54

42. Baj A, Moro E, Bistoletti M, Orlandi V, Crema F, Giaroni C. Glutamatergic signaling along the microbiota-gut-brain axis. Int J Mol Sci. 2019;20(6):1482.

43. Harris RE, Sundgren PC, Craig AD, Kirshenbaum E, Sen A, Napadow V, Clauw DJ. Elevated insular glutamate in fibromyalgia is associated with experimental pain. Arthritis Rheum. 2009;60(10):3146-52.

44. Gerdle B, Ernberg M, Mannerkorpi K, Larsson B, Kosek E, Christidis N, Ghafouri B. Increased interstitial concentrations of glutamate and pyruvate in vastus lateralis of women with fibromyalgia syndrome are normalized after an exercise intervention - A case-control study. PLoS ONE [Electronic Resource. 2016;11(10):e0162010.

45. Zunhammer M, Schweizer LM, Witte V, Harris RE, Bingel U, SchmidtWilcke T. Combined glutamate and glutamine levels in pain-processing brain regions are associated with individual pain sensitivity. Pain. 2016; 157(10):2248-56.

46. Foerster BR, Petrou M, Edden RAE, Sundgren PC, Schmidt-Wilcke T, Lowe SE, Harte SE, Clauw DJ, Harris RE. Reduced insular gamma-aminobutyric acid in fibromyalgia. Arthritis Rheum. 2012;64(2):579-83.

47. Valdes M, Collado A, Bargallo N, Vazquez M, Rami L, Gomez E, Salamero M. Increased glutamate/glutamine compounds in the brains of patients with fibromyalgia: a magnetic resonance spectroscopy study. Arthritis Rheum. 2010;62(6):1829-36.

48. Lee SH, Yun Y, Kim SJ, Lee E-J, Chang Y, Ryu S, Shin H, Kim H-L, Kim $\mathrm{H}-\mathrm{N}$, Lee $\mathrm{JH}$. Association between cigarette smoking status and composition of gut microbiota: population-based cross-sectional study. J Clin Med. 2018;7:282.

49. Lukić I, Getselter D, Ziv O, Oron O, Reuveni E, Koren O, Elliott E. Antidepressants affect gut microbiota and Ruminococcus flavefaciens is able to abolish their effects on depressive-like behavior. Transl Psychiatry. 2019;9:133.

50. Cussotto S, Clarke G, Dinan TG, Cryan JF. Psychotropics and the microbiome: a chamber of secrets. Psychopharmacology. 2019;236(5):1411-32.

51. Pozuelo M, Panda S, Santiago A, Mendez S, Accarino A, Santos J, Guarner F, Azpiroz F, Manichanh C. Reduction of butyrate- and methane-producing microorganisms in patients with irritable bowel syndrome. Sci Rep. 2015;5:12693.

52. Canani RB, Costanzo MD, Leone L, Pedata M, Meli R, Calignano A. Potential beneficial effects of butyrate in intestinal and extraintestinal diseases. World J Gastroenterol. 2011;17(12):1519-28.

53. Gerdle B, Soderberg K, Salvador Puigvert L, Rosendal L, Larsson B. Increased interstitial concentrations of pyruvate and lactate in the trapezius muscle of patients with fibromyalgia: a microdialysis study. J Rehabil Med. 2010;42(7):679-87. 
54. Scheijen JLJM, Hanssen NMJ, van de Waarenburg MPH, Jonkers DMAE, Stehouwer CDA. Schalkwijk CG: L(+) and D(-) lactate are increased in plasma and urine samples of type 2 diabetes as measured by a simultaneous quantification of $\mathrm{L}(+)$ and $\mathrm{D}(-)$ lactate by reversed-phase liquid chromatography tandem mass spectrometry. Exp Diabetes Res. 2012, Article ID:234812.

55. Rao SSC, Yu S. Response to Sachdeva et al: brain fogginess and SIBO is not a mirage. Clin Transl Gastroenterol. 2018;9:e194.

56. McAllister SJ, Toussaint LL, Williams DA, Hoskin TL, Whipple MO, Vincent A. Perceived dyscognition reported by patients with fibromyalgia. Clin Exp Rheumatol. 2016;34(2):S48-54.

57. Connors J, Dawe N, Van Limbergen J. The role of succinate in the regulation of intestinal inflammation. Nutrients. 2018;11(1):25.

58. Sigthorsson G, Tibble J, Hayllar J, Menzies I, Macpherson A, Moots R, Scott D, Gumpel MJ, Bjarnason I. Intestinal permeability and inflammation in patients on NSAIDs. Gut. 1998;43:506-11.

59. Lambert GP, Schmidt A, Schwarzkopf K, Lanspa S. Effect of aspirin dose on gastrointestinal permeability. Int J Sports Med. 2012;33(6):421-5.

60. Camilleri M, Nadeau A, Lamsam J, Linker Nord S, Ryks M, Burton D, Sweetser S, Zinsmeister AR, Singh R. Understanding measurements of intestinal permeability in healthy humans with urine lactulose and mannitol excretion. Neurogastroenterol Motil. 2010;22(1):e15-26.

61. Leech B, Schloss J, Steel A. Association between increased intestinal permeability and disease: a systematic review. Adv Integr Med. 2018;6:2334.

62. Camilleri M. Leaky gut: mechanisms, measurement and clinical implications in humans. Gut. 2019;68:1516-26.

63. Lauritano EC, Valenza V, Sparano L, Scarpellini E, Gabrielli M, Cazzato A, Ferraro PM, Gasbarrini A. Small intestinal bacterial overgrowth and intestinal permeability. Scand J Gastroenterol. 2010;45(9):1131-2.

64. Park JH, Park DI, Kim HJ, Cho YK, Sohn Cl, Jeon WK, Kim Bl, Won KH, Park $\mathrm{SM}$. The relationship between small-intestinal bacterial overgrowth and intestinal permeability in patients with irritable bowel syndrome. Gut Liver. 2009;3(3):174-9.

65. Fukuda Y, Bamba H, Okui M, Tamura K, Tanida N, Satomi M, Shimoyama T, Nishigami T. Helicobacter pylori infection increases mucosal permeability of the stomach and intestine. Digestion. 2001;63(Suppl. 1):93-6.

66. Serena C, Ceperuelo-Mallafré V, Keiran N, Queipo-Ortuño MI, Bernal R, Gomez-Huelgas R, Urpi-Sarda M, Ma S, Pérez-Brocal V, Andrés-Lacueva C, et al. Elevated circulating levels of succinate in human obesity are linked to specific gut microbiota. ISME J. 2018;12:1642-57.

67. Yu D, Cheeseman F, Vanner S. Combined oro-caecal scintigraphy and lactulose hydrogen breath testing demonstrate that breath testing detects oro-caecal transit, not small intestinal bacterial overgrowth in patients with IBS. Gut. 2011;60(3):334-40

68. Rezaie A, Buresi M, Lembo A, Lin H, McCallum R, Rao S, Schmulson M, Valdovinos M, Zakko S, Pimentel M. Hydrogen and methane-based breath testing in gastrointestinal disorders: the north American consensus. Am J Gastroenterol. 2017;112(5):775-84.

69. Pimentel M, Chow EJ, Hallegua D, Wallace D, Lin HC. Small intestinal bacterial overgrowth: a possible association with fibromyalgia. J Musculoskelet Pain. 2001;9(3):107-13.

70. Mansız-Kaplan B. AB0905 May chronic constipation-induced chronic inflammation affect the onset and severity of fibromyalgia symptoms? Ann Rheum Dis. 2019;78(Suppl. 2):1919.

71. Kunkel D, Basseri RJ, Makhani MD, Chong K, Chang C, Pimentel M. Methane on breath testing is associated with constipation: a systematic review and meta-analysis. Dig Dis Sci. 2011;56(6):1612-8.

72. Sharon G, Sampson TR, Geschwind DIH, Mazmanian SK. The central nervous system and the gut microbiome. Cell. 2016;167(4):915-32.

\section{Publisher's Note}

Springer Nature remains neutral with regard to jurisdictional claims in published maps and institutional affiliations.

Ready to submit your research? Choose BMC and benefit from:

- fast, convenient online submission

- thorough peer review by experienced researchers in your field

- rapid publication on acceptance

- support for research data, including large and complex data types

- gold Open Access which fosters wider collaboration and increased citations

- maximum visibility for your research: over $100 \mathrm{M}$ website views per year

At BMC, research is always in progress.

Learn more biomedcentral.com/submissions 